\title{
NATIONAL SECURITY POLICY IN SWITZERLAND
}

\begin{abstract}
The national security policy of Switzerland is based upon the specifics of the Swiss country and it is distinguished with great complicacy and complexity. Hence, the examination of the security policy should be founded of its complete comprehension and thorough perception of the conditions in order to avoid improvisation and partiality. This signifies that the security policy should be rationally founded and to synthetize the efforts of all of the security actors in order to provide the necessary level of security, for the society, the nation, and for the citizens. Generally, the altered nature of security threats conditioned the need for redefining the security policy of Switzerland and also imposed for adoption of new approaches toward security. Accepting such reality, Switzerland has to adjust to the new circumstances for the protection of the national interests and the neutrality policy. The Adaptation of the security system in the new security environment has to be a reflection and result of the evident general overall inclusion of all the subjects, which are authorized for enforcing the security policy.
\end{abstract}

Keywords: SWITZERLAND, SECURITY, SECURITY POLICY, NATIONAL SECURITY, SECURITY SYSTEM

\section{Introductory remarks}

Switzerland is a multinational, multilingual, religiously and economically complex community, and it is consisted of four main lingual and cultural domains: German, French, Italian and Romans (Radosavljević, 2011, 102). Even though most of the citizens speak German, the Swiss national identity pulls its roots from a common historical background, sharing the values such as federalism and direct democracy as well as Alpine symbolism. On the coins and postal stamps a Latin denomination is used (Helvetia, as was the name of the country in historic times, yet even today it has a symbolic significance), instead some of the four main spoken languages. The number of the population in July 2018 amounted 8,292,809 million citizens, with an average population density of around 195 citizens per $\mathrm{km}^{2}$. By ethnic groups in $2017,70.3 \%$ have declared themselves as Swiss, German $4.2 \%$, Italian $3.2 \%$, Portuguese $2.6 \%$, French $2 \%$, Kosovar 1\%, and other 18.7\% (Discover Switzerland, Geography, 2017), in Switzerland in 2016 is spoken mainly Ger- 
man (or Swiss German - official language) 62.8\%, French (official) 22.9\%, Italian (official) $8.2 \%$, English $5.1 \%$, Portuguese 3.7\%, Albanian $3.1 \%$, SerbianCroatian 2.4\%, Spanish $2.3 \%$, Roman (official) $0.5 \%$ and other $7.5 \%$ (The World Factbook: Switzerland, 2019; Clarke\&White, 1989).

Switzerland is one of the most developed countries in the world, with the highest nominal wealth per adult, and has the eighth highest GDP in the world according to the International Monetary Fund. Switzerland is on the top or among the top ten countries for several indicators of national performance, including government transparency, civil freedoms, life quality, economic competitiveness and human development. The gross-domestic product of the country in 2017 amounted 523.1 billion dollars. ${ }^{1}$ GDP per capita for 2017 amounted 62,100 \$ and is calculated, i.e. it depicts GDP based on the purchasing power parity divided by the population in the same year. It is interesting to mention that the budget of Switzerland (which includes revenues, expenditures and capital expenditures) in 2017 amounted 242.1 billion dollars. In 2017, 0.68\% from the GDP was allocated for the military expenditures in the country (Ibid.).

Switzerland borders five countries, including: Austria on the north (border length of $158 \mathrm{~km}$ ), France on the west (525 km border line), Italy on the south (698 $\mathrm{km}$ border line), Liechtenstein on the east (41 km border length), and Germany on the north ( $348 \mathrm{~km}$ border line). The total length of the border is around 1,770 $\mathrm{km}$. Spreading across the northern and southern slopes of the Alps in Western and Central Europe, Switzerland is surrounded by various landscapes and climate in an area of $41.285 \mathrm{~km}^{2}$. The southern part of the country, distinguished with a greater mountainous area, is far less populated than the north of the country. Many glaciers are found between the high valleys of the Swiss Alps, with a total area of $1.063 \mathrm{~km}^{2}$. Several larger rivers flowing in four main directions across Europe, such as Rhine, Inn, Ticino and Rhône spirit from there. The hydrographic network includes some of the biggest freshwater surfaces in Central and Eastern Europe, among which are the Geneva Lake, Bodensee Lake and the Lake Maggiore. Switzerland has more than 1.500 lakes and contains 6\% of the European freshwater. The biggest lake is the Geneva Lake located west in Switzerland, dividing the territory with France. Rhône is the most significant confluent of the Geneva Lake (Discover Switzerland, Geography, 2017). This colourful landscape makes the country a famous tourist destination with its ski cen-

${ }^{1}$ This record gives a gross domestic product (GDP) all the value of all final goods and services produced in one country in a given year. The nation's GDP per purchasing power parity is the sum and value of all goods and services produced in the country valued at prices levels prevailing in the USA in the given observed year. Most of the economists prefer this measure when scoping the well-being per capita and when they compare the living conditions or the utilization of the resources throughout the countries. See: Ibid. 
tres and hiking trails. Banking and financing are the key industries, and Swiss watches and chocolate are world famous (Switzerland-Country Profile, 2019).

Numerous international offices were located in Switzerland ever since 1830, when peace communities are established in Geneva, organizing international congresses from 1848. The peace bureau was opened in Bern in 1891 where prominent figures with a strong influence over the European policies in that time took part. Also, in Switzerland there are the headquarters of the Red Cross, established by the founder of the Red Cross Henri Dunant. Basically, Switzerland is a member of several international organizations such as: ADB (non-regional member), AfDB (non-regional member), Australia Group, BIS, CD, CE, CERN, EAPC, EBRD, EFTA, EITI (country of implementation), ESA, FAO, FATF, G-10, IADB, IAEA, IBRD, ICAO, ICC (National council), ICCt, ICRM, IDA, IEA, IFAD, IFC, IFRCS, IGAD (partners), ILO, IMF, IMO, IMSO, Interpol, IOC, IOM, IPU, ISO, ITSO, ITU, ITUC (NGOs), LAIA (observer), MIGA, MINUSMA, MONUSCO, NEA, NSG, OAS (observer), OECD, OIF, OPCW, OSCE, Pacific Alliance (observer), Paris Club, PCA, PFP, Schengen Convention, UN, UNCTAD, UNESCO, UNHCR, UNIDO, UNITAR, UNMISS, UNMOGIP, UNRWA, UNTSO, UNWTO, UPU, WCO, WHO, WIPO, WMO, WTO, ZC (The World Factbook: Switzerland, 2019).

\section{Cultural and Historical Specifics}

When the Habsburg king Rudolf, the first German emperor from this dynasty had died in 1291, the people from Uri, Schwyz and Unterwalden feared that the Habsburgs would try to gain influence on their territories. That is why they swore that they would help each other against anyone which would try to subdue them. The Treaty from 1291 for establishing of this confederation of alliances was called Bundesbrief (the Eternal Alliance) in German and is translated as "The Federal Charter", pointing out that the character of this alliance was more serious and durable. These cantons were formally part of the German Kingdom. The purpose of their forming, similar to the Greek confederate creations was military-defensive, since the Habsburg dynasty counterpoised a subtle threat for these territories. This alliance played its role in the coping with the Habsburg dynasty and the Holy Roman Empire during the XIV century with which the Swiss confederation attained its independency from the Holy Roman Empire in 1499. In the following years, the reformation in Switzerland had divided the land on two parts: the progressive towns such as Zurich, Basel, Berne, Neuchâtel, and Geneva, which turned to the new confession, while the conservative, rural areas in central Switzerland (including Lucerne) remained Catholic. When the Pope began an internal reform in order to re-gain the influence, Lucerne took that possibility with contentment and called upon the Jesuit order to organize its schools upon this concept. Switzerland, after few battles, on October $24^{\text {th }}$ 
1648 gained independence from the Roman-German kingdom and built a tradition of neutrality. As such, the regulation system in Switzerland existed until the beginning of the era of Napoleon Bonaparte. During the ruling of Napoleon Bonaparte (1798-1803) Switzerland's name was titled as the Helvetic Republic. Inspired by the French revolution, the liberals in Western Switzerland opposed to the non-democratic ruling of the old members of the Swiss Confederation in the other parts of the country and called upon French support in 1798. The soldiers of Napoleon Bonaparte occupied Switzerland and imposed a central government. However, soon (year 1803) it was obliged to establish some federal elements. After the Napoleonic wars 1803-1815, the concept for pacifism (Latin: pacificus - love for peace) was developed as an idealistic peace movement motivated by religion and ethics, with rejection of use of any kind of force, even in the form of measures for peace keeping by the army or in cases of defensive war. Since Napoleon was defeated in Russia and in Waterloo, Switzerland had reversed to the extreme federal structures in 1815. Still, the cantons (federal states) St. Gallen, Graubünden, Aargau, Thurgau, Ticino, Vaud, Valais, Neuchâtel and Geneva became full-fledged and free members of the confederation, instead of their former status as partial members or even subject territories (A Short Paragraph of the History of Switzerland, 2010).

In 1815, after the Vienna Congress, Switzerland received its physiognomy with 22 cantons with confederate arrangement. From 1815 to 1848, the liberals and conservatives debated for the structure of Switzerland after the French revolution. In each canton, there were liberals, as well as conservatives. The majority on one or other side was mostly insignificant, so the governments changed from time to time in many cantons. When the cantons with conservative governments made a secret arrangement with Austria against the liberals in 1846, the civil war („Sonderbundskrieg“) was inevitable. Still, thanks to Henri Dufour, general of the liberal soldiers, this war had lasted only few days and took 86 casualties and around 500 wounded soldiers. After this, the road was liberated for a new political system and "the loose confederation" almost without common structures, was substituted with a confederation of 25 cantons (today: 26), relatively autonomous cantons (federal states) with enforced central structures by the USA model. The new principles were quoted in the Constitution of Federative Switzerland in $1848^{2}-$ and basically they are still valid, despite the two "total revisions" made in 1874 and in 1999 in regard of the: statement on civil rights; new federal structure with central and cantonal parliaments and governments; National

\footnotetext{
${ }^{2}$ In 1848 a new Constitution was brought according to which it was prohibited any kind of division, respectfully, forming of alliances and Switzerland became a modern confederation, and the authonomy of the cantons was abolished with the 1848 Constitution. Bern became a guildhall of the Parliament.
} 
Parliament with two chambers: „Nationalrat" (House of representatives according to the number of population) and "Ständerat" (2 delegates from each canton). Federal responsibility for foreign affairs and public services with more than regional significance (currency, customs, postal service and telecommunications); federal court of justice; and cantonal autonomy remained undisputed in broad sectors of administration (education, hospitals, police, justice, etc.) (History of Switzerland: Federal Constitution 1848, 2010).

Therefore, since 1848 until 1874 certain unique instruments were developed for the Swiss form of so-called direct democracy with frequent referendums (several per year) and a possibility for the citizens to modify the Constitution by gathering signatures. The reaction of the conservative representatives was excessive again, especially the Catholic Church, which led to certain restrictions of the influence of the church and the necessary majority in public opinion for the revised constitution.

The constitutionality from 1848 later altered in 1874, had substituted the confederation with a centralized federal government. On the initiative of Henry Dunant in 1864, the Red Cross was established in Geneva. The integration of the Catholics into the new confederation followed in 1891, after the election of the first catholic in the Federal Council. In 1920, Switzerland became a member of the League of Nations. The Palace of nations (Palais des Nations) built between 1929 and 1938, was the headquarters of the League of the Nations. Today, it serves as the European headquarters of the United Nations. During World War I, Switzerland was "isolated" from the world, because all the neighbouring countries were participating in the war. During the war, there were tensions among the people: the ones who spoke the Swiss-German language were on the side of Germany, the French-Swiss on the other hand, were on the side with France. For the first time a general was elected for security of the Swiss border. The refugees from other countries also felt the food shortage, the money deficit as well as other problems in Switzerland. During the Second World War, the Germans made a detailed plan for invading Switzerland, but the attack never occurred. Switzerland had maintained to remain neutral thanks to the economic concessions for Germany and luckily, the big events during the war postponed the invasion. The attempt of one small Nazi party in Switzerland for provoking unification with Germany had not succeeded. The mass mobilization was enforced under the leadership of General Henri Guisan. Switzerland had experienced a wave of industrialization and railroad construction. The Swiss had granted women the right to vote in 1971, and on January $1^{\text {st }} 1979$, after several demonstrations by its citizens the canton Jura gained independency from the canton of Bern. That is how canton Jura became the youngest canton in Switzerland (A Short Paragraph of the History of Switzerland, 2010; Steiner, 1971). 


\section{Institutions responsible for creating the security policy}

The political system of Switzerland is characterized by decentralization and direct democracy. The multilingual country is most often led by a broad coalition in which members of the four biggest political parties represented in the parliament are included.

Switzerland is organized on three territorial-political levels: on a federal state level, on a cantonal level and on a municipal level. The organization of the government on a federal level is defined by the Federal Constitution. The highest legislative body is the Federal Assembly (Bundesversammlung). It is consisted of two chambers: the National Council (Nationalrat) or the Lower House, which represents all the citizens of Switzerland and is elected by election units (each canton is an election unit, and the number of representatives from every unit depends on the number of citizens of each canton, respectively one representative is elected on 28.000 citizens), and by the Cantonal (State) Council (Ständerat) or the Upper House which is consisted of 46 members, and in which the cantons send two of their representatives. ${ }^{3}$ Each canton has two representatives, and the half cantons have one each.

The Federal Government (Bundesrat) along with the Federal Office (Bundeskanzlei) which is the administration of the federal government is governed by the Federal Chancellor. ${ }^{4}$ The Federal Chancellor is also the President of the Swiss Confederation, appointed by the Federal Assembly from the ranks of the Federal Government on an annual basis. After the expiration of the mandate, one cannot be immediately re-elected as a president; another member of the Federal Government comes to that place (Radosavljević, 2011, 103-112). The Federal government is consisted of seven members who are being appointed by the Federal Assembly on every first session after the general elections for the National council, respectfully, every four years. The members of the federal government are not only limited for a possibility for re-election, and they remain in power for a longer time (10 years in average), and after four-year elections, the composition of the Federal government almost never changes completely, usually one up to three ministers are changed. A member of the government cannot simultaneously perform another public function, and that is why they cannot be a member of the Federal assembly. The Federal government is a coalition formation composed by two members of the three ruling parties and one from the smaller parties and it is a result of the real ratio of the political forces of the country (Steiner, 1971, 75-120).

3 "Bundesvervassung der Schweizerischen Eidgenossenschaft", Article 39/2.

${ }^{4}$ In the constitutional system of Switzerland, the Federal Chancellor is not the Prime Minister, such as in the German constitutional system. Here, the Federal Chancellor is governed by the federal administration and its function is mainly of administrative nature. 
The cantonal level of governance is designated by its sole constitutions. The federal constitution defines Switzerland as a federal country comprised by 26 cantons $^{5}$ with far reaching autonomy. Since the Westphalia Peace (in 1648), until the foundation of Federal Switzerland (1848), every canton was completely sovereign state with its own customs, army and currency. The newest canton is Jura, which had separated from Bern in 1979.

Today, in every realm of state activity the federal legislation attempts to establish a minimal amount of national standard on one hand, and allows a respective possibility for self-determination of the cantons and the communities on the other hand. The majority of the electorate approves these fundamental principles of the Swiss politics again and again - by rejecting the centralistic legislations and accepting the federal laws on the referendums (Switzerland's Political System and Government, 2019). In order for the cantonal constitution to take effect, it has to be approved by the Federal Assembly and it would do so if the cantonal constitution fulfils two basic conditions: if it is not in opposition with the federal constitution and federal laws and if the citizens of the canton approve it on a referendum. Most often, the highest authority is a monochromatic cantonal parliament (The Federal Council, 2018). The manner in which the cantonal parliament is appointed warries in each canton, the proportions are dominant, even though sometimes majority elections are held. Each canton has an executive body, which is most often called the Governing Council (Regierungsrat), which is directly elected by the citizens in all of the cantons. There are differences in the organization of the courts on a cantonal level. The judges are appointed by the citizens and in some cases by the cantonal parliament.

\section{National security policy}

Switzerland founds its security policy on neutrality, and neutrality signifies not to take side in war. The determining factors designating the Swiss policy of neutrality are guided by the national interest, by the right to neutrality, by the international situation, as well as the tradition and the history. This standpoint is always flexibly adjusted to the circumstances and is applied by the interests of the country, respectably the history that not only taught Switzerland how to prevent external conflict, but has also taught it about the importance for active solidarity, through the worldwide engagement of the International Committee of the Red Cross and the establishment of diplomatic offices (Swiss Security Policy, 2018).

In Switzerland, land of several cultures, languages and religions, the neutrality always serves to guarantee the internal cohesion, whereof the

5 The term "canton" (German: Kantone, French: cantons, Italian: cantoni, Romansh: chantuns) derives from a French origin and signifies "corner" or "district". 
principle of neutrality also is applied for relativization of conflicts within the confederation. For example, the change of neutrality in the active foreign policy in the XVI century (religious conflict) would have led to unbearable tensions in XIX and XX century, the accusations with Germany or with France would provoke and hustle the Confederation into a national crisis. Hence, without external neutrality, the internal cohesion would be unimaginable (Ibid.).

Today, the Swiss security policy is directed towards maintaining the neutrality, the freedom to act, the self-determination and integrity of Switzerland and its citizens, protection of their vital resources from direct and indirect threats and hazards as well as contribution toward peace and stability outside the borders (Switzerland's Political System and Government, 2019). The instruments for enforcing the Swiss security policy include its foreign policy, the armed forces, the civil protection system, its intelligence service and the police, its economic policy, customs administration and the civil service. All of these entities assist to prevent, to deter and to overcome the threats and hazards toward Switzerland (Swiss Security Policy, DDPS, n.d.).

In accordance with the Military doctrine from 2017, which was based upon the Security policy report from 2016, Switzerland takes into account the direct military threat, yet it believes that nowadays the potential threats include: espionage, cyber-attacks, operations for external influence and sabotage, as well as activities from non-state groups. By these assessments, the Swiss government plans to decrease the size of its armed forces after the mobilization of $40 \%$ (up to 100.000 troops), which reflects the estimate that in the system based on the militia call there will not always be enough personnel for active service in times of conflict. Still, these smaller forces will utilize additional weapons. This plan for development of the armed forces was approved in March 2016 and it emphasizes the improvement of the combat readiness, the training and the armament. The Swiss approach is moving toward a more flexible model, in which different units will be called for active service gradually and in different periods (Swiss Security Policy, 2018).

The Swiss security policy puts its main focus on the cyber-attacks. It is considered, as it is quoted in the National Strategy for Protection of Cyber Risks in Switzerland 2018-2022 where a comprehensive digital connection is already a characteristic of the Swiss society, economy and country, and the rapid technological development will continue to move this progress. The process opens vast opportunities, and Switzerland is ready to utilize in order to enable and widen the social welfare in the country for a longer time interval. Still, the Strategy states that it has to be taken into foresight the fact that digitalization does not only bring opportunities, but also risks connected with the increased dependency on information and communication, which makes the country prone to defects, disruptions and misuse of these technologies (Switzerland's Security 2017 Situation Report of the Federal Intelligence 
Service FIS, 2017). How relevant this vulnerability is, can be seen in regard of the development of threats in the cyber space. Computer crime, accumulation of intelligence activities through cyber attacks, cases of cyber sabotage against the critical infrastructures such as hospitals and power supply, dissemination of stolen or manipulated information for the purpose of disinformation and propaganda, as well as increase of the hybrid forms of conflict in which cyber-attacks are used in order to destabilize the countries and societies are threats which demand additional elaboration about how various these threats are and how fast they develop. The combination of the increased dependency of the functioning of the IT and the increased threat signifies that the risks that emanate from it, which we call cyber risks, necessarily have to be taken into consideration in the development of the digital society. From a security point of view, there have to be measures undertaken for protection of the independence and the security of the country from the occurrence or the intensification of threats and hazards in the cyber space. From an economic and social policy point of view, Switzerland has to protect itself from the cyber threats in order to be capable to lead a consistent utilization of the opportunities that are offered by digitalization and to sustain its locational advantage as a safe country. Still, a complete protection from cyber risks cannot be achieved with proportional measures. Therefore, Switzerland has to increase its elasticity to cyber incidents (National strategy for the protection of Switzerland against cyber risks, 2018, 2-7).

Beside the threats from the cyber risks, the global strategy of Switzerland covers a broad spectrum of effective instruments for fight against terrorism and terrorism financing, organized crime and money laundering. Regarding terrorism prevention and combating, Switzerland develops an effective legislature based upon a quick processing in the sphere of mutual cooperation and legal assistance in criminal cases, especially for the purpose of blocking funds. In addition, it introduced a federal law for allocation of confiscated assets (LVPC), designating the procedure for sharing of those means between Switzerland and foreign countries (Profiles on Counter-Terrorist $\mathrm{Ca}$ pacity Switzerland, 2014, 1-3).

It is also encouraging for Switzerland to strengthen the international and the inter-institutional cooperation and coordination, the support of global and regional initiatives and events related to prosecution (bringing terrorists to face justice), investigation (special investigation techniques) and terrorism financing (Swiss Security Policy, DDPS, n.d.)

In the achievement of the security policy in Switzerland an appropriate place belongs to the Sector for Security Policy in the Federal Department of Defence, Civil Protection and Sport - DDPS. Within its framework, the Sector for security policy has certain credential authorities, such as: a) it manages politically sensitive projects such as the creation of the security policy report and the reports to the parliament for accomplishment of its goals by 
the armed forces; $b$ ) makes efforts to ensure that within its projects, procurements and missions, the armed forces take into account the political directives of the Supremes; c) it represents the interests of the armed forces on an inter-ministerial level regarding the export of military materials, military and civilian peace promotion, as well as creation of reports on the external or the integrative policy of Switzerland d) provides contact for security policy issues, not solely within the framework of the Department, but also outside, for example, for associations and universities and stimulates a public debate for the security policy etc (Swiss Security Policy, DDPS, n.d.).

\section{Conclusion}

The security policy of Switzerland is focused on the realization of the fundamental interests in the country. There is no doubt that the security policy has a specific place regarding that it is one of the most significant securety paradigms which create the necessary assumptions for a progressive development in the security sphere. Undoubtedly, it contributes for shaping the measures with a security character in the provision of the necessary political neutrality, and whose action will be allowed within the constitutional framework. It simultaneously enables the political ideals to merge into a political security doctrine with which it will endeavour to produce an optimal concept and strategy of procedures for achievement of the designated goals.

An efficient security policy can exist only if it is embedded upon scientific acknowledgments. It counterpoises a substrate in the shaping of its philosophical framework and serves as a global foundation for a decisive designation of the responsibilities of every subsystem in society when it comes to question the designated issues (economic, social, ecological, political, etc.).

The national security policy of Switzerland counterpoises a significant framework through which the country provides security for the state and for its citizens and is usually presented as an integral document. This document synthesizes the general efforts for a broader security, but also, it underlines the key interests for the national and defines the manners for resolving the current and potential threats for the security of the country. 


\section{References}

Clarke, M. and White, B. (ed.) (1989). Understanding Foreign Policy: The Foreign Policy Systems Approach. London: Edward Elgar, 1989

Deutsch, K. W. (1976). Die Schweiz als ein paradigmatischer Fall politischer integration. Bern: Verlag Paul Haupt.

Federal Intelligence Service Swiss Confederation (2017). Switzerland's Security 2017 Situation Report of the Federal Intelligence Service FIS.

Hilsman, R. (1993). The Politics of Policy Making in Defense and Foreign Affairs. Englewood Cliffs: Prentice Hall.

Lieber, R. (1972). Theory and World Polities. Cambridge, Mass: Winthrop Publishers.

Maddex, L. R. (1996). Constitutions of the World. London: Routledge.

Mangold, P. (1990). National Security and International Relations. London and New York: Routledge.

Matthew, A. R. (2002). Dichotomy of Power, Nation versus State in World Politics. Lanham: Lexington Books.

National strategy for the protection of Switzerland against cyber risks (NCS) 2018-2022

Ostojić, D. (2003). Drźave sveta 2003. Beograd: No Limit Books.

Parliamentary Oversight of the Security Sector-Principles, mechanisms and practices (2003). Inter-Parliamentary Union, Geneva Centre, Democratic Control of Armed Forces, Geneva-Belgrade.

Radosavljević, D. (2011). Savremeni politički i pravni sistemi. Novi Sad: USEE Fakultet za pravne I poslovne studije.

Sarkesian, S.C. (1995). US National Security, $2^{\text {nd }}$ ed. Lynne Rienner Publishers.

Steiner, J. (ed.). (1971). Das politische System der Scweiz. München: R. Piper \& Co. Verlag.

Switzerland's Security (2017). Situation Report 2017 of the Federal Intelligence Service FIS.

White Paper on Neutrality Annex to the Report on Swiss Foreign Policy for the Nineties of 29 November 1993

Бакрески, О. (2018). Безбедносни системи-компаративна анахиза. Скопје: Филозофски факултет, Скопје. 
Websites

A Short Paragraph of the History of Switzerland, (2010) http://history-switzerland. geschichte-schweiz.ch/swiss-history-summary.html viewed: 21.4.2019

Discover Switzerland, Geography, (2017). https:/www.eda.admin.ch/aboutswitzerland/en/home/umwelt/geografie.html, viewed: 23.4.2019

History of Switzerland: Federal Constitution 1848, (2010). http://history-switzerland.geschichte-schweiz.ch/switzerland-federal-constitution-1848.html viewed: 21.4.2019.

Swiss Security Policy, (2018). https://www.globalsecurity.org/military/world/europe/ch-policy.htm viewed: 21.4.2019

Swiss Security Policy, DDPS, n.d. https://www.vbs.admin.ch/en/internationaltopics/security-policy.html viewed: 21.4.2019

Switzerland - Country Profile, (2019). https://www.nationsonline.org/oneworld/switzerland.htm viewed: 21.4.2019

Switzerland's Political System and Government, (2019). http://swiss-governmentpolitics.all-about-switzerland.info/ viewed: 21.4.2019

The Federal Council (2018). Federal Constitution of the Swiss Confederation of 18 April 1999 (Status as of 23 September 2018). https://www.admin.ch/opc/en/classified-compilation/19995395/index.html viewed: 21.4.2019

The World Factbook: Switzerland, (2019). https://www.cia.gov/library/publications/the-world-factbook/geos/sz.html viewed: 21.4.2019 